\title{
Corporate governance codes and their contents: An analysis of Eastern European codes
}

\author{
Niels Hermes, Theo J.B.M. Postma, Orestis Zivkov**
}

Existing literature suggests that the contents of corporate governance codes are similar due to external forces, such as increased integration of countries in the global economy, the increased role of foreign institutional investors and recommendations on corporate governance practices of international organisations. This paper analyzes and compares the code contents of seven Eastern European countries with respect to generally accepted best practice recommendations on disclosure rules, strengthening shareholder rights and modernising boards. We show that for some countries the contents of the country codes are actually rather different as compared to these best practices, suggesting that domestic forces related to country-specific characteristics of corporate governance systems may have helped shaping the contents of corporate governance codes.

Die bisherige Fachliteratur argumentiert, dass die Inhalte der Corporate Governance Kodizes relativ ähnlich sind aufgrund von externen Faktoren wie der wachsenden Integration der Länder in die globale Wirtschaft, der verstärkten Rolle von ausländischen institutionellen Investoren und den Empfehlungen für Corporate Governance - Praktiken in internationalen Organisationen. Dieser Aufsatz analysiert und vergleicht die Inhalte der Kodizes von sieben osteuropäischen Ländern im Hinblick auf allgemein akzeptierte „best practice“ - Empfehlungen bezüglich Offenlegung, Stärkung der Aktionärsrechte und der Modernisierung der Führungsgremien. Wir zeigen auf, dass in einigen Ländern die Kodizes stark von den „best practice“ Empfehlungen abweichen, was darauf hinweist, dass lokale Kräfte mit Bezug auf die Eigenheiten des nationalen Corporate Governance Systems die Entwicklung der Kodizes wesentlich geprägt haben.

Keywords: corporate governance, corporate governance codes, Eastern Europe

* Manuscript received: 01.05.06, accepted: 23.10.06 (2 revisions)

** Niels Hermes, Associate Professor, University of Groningen, Faculty of Management and Organization. Main research areas: Coperate governance, international finance and development finance. Corresponding address: c.1.m.hermes@rug.nl

Theo J.B.M. Postma, Associate Professor, University of Groningen, Faculty of Management and Organization. Main research areas: Coperate governance and innovation. Orestis Zivkov, Researcher, University of Groningen, Faculty of Managemant and Organization. Main research areas: Coperate governance, ownership structure. 


\section{Introduction}

Since the early 1990s, Eastern European countries have made strong efforts in terms of the transition to a market economy. This is particularly true with respect to privatisation of former state-owned enterprises, trade liberalisation, the development of domestic financial markets and their integration to global capital markets, and the general institutional setting in terms of regulations and law systems. These developments helped to shape a corporate governance system in these countries that has elements of both the continental stakeholder model and the Anglo-Saxon shareholder model (Berglöf/Pajuste 2005). The developments also triggered a demand for rules regarding the governance of companies in order to mitigate agency problems between managers and owners and to protect minority shareholders' interests.

One way to settle these demands is by introducing codes of corporate governance. These codes reflect best practices with respect to the governance of firms, including issues such as board membership and board composition, board practices, selection of board members, remuneration and dismissal of management, auditing and information disclosure, and relationships with shareholders. These best practices aim at stimulating governance structures of companies that reduce principal-agent problems between manager and owners, as well as between controlling and minority shareholders as much as possible. In recent years, several Eastern European countries have established corporate governance codes. One of the first countries to have a code was Romania (in 2000), other countries, such as Slovenia and Hungary followed a few laters later (in 2004). By early 2006, twelve Eastern European countries had established their own code.

Some authors have argued that corporate governance codes and their contents tend to convergence and that this is caused by the way codes diffuse around the world (Aguilera/Cuervo-Cazurra 2004). The argument is that processes of globalization, liberalization of markets, the presence of powerful foreign investors and recommendations on corporate governance practices of international organisations lead to pressure on national governments, institutions and companies, to conform to internationally accepted best practices of corporate governance at the national level. Accepting these best practices increases the attractiveness of countries and companies for foreign investors.

At the same time, however, it has also been argued that a country code's contents may also be determined by country-specific factors and institutions (which we call domestic forces), such as financial and legal systems, which are directly related to corporate governance structures of countries (Aguilera/Cuervo-Cazurra 2004). If these country-specific factors are important in shaping code contents, then this may lead to codes that are to a greater or lesser extent different from internationally accepted best practices. 
In 2003, the European Commission published a document, Communication 284, or COM-284 (European Commission 2003), in which it discusses how corporate governance in the European Union could be enhanced. In particular, the document provides recommendations with respect to corporate governance disclosure, strengthening shareholder's rights and modernising the board of directors. The contents of the document may be seen as internationally accepted best practices of corporate governance that put external pressure on the introduction and the contents of codes in the European Union countries. In this respect, the document may also be important in shaping the contents of codes in Eastern Europe, and especially in those countries that have become, or are in the process of becoming, a member of the European Union. This view is supported by those who have claimed that the codes of Eastern European countries were to a large extent determined by demands resulting from the process of accession to the European Union, as well as by the contents of the UK and USA codes from which they more or less were copied (Berglöf/Pajuste 2005).

This paper examines to what extent the contents of corporate governance codes of seven Eastern European countries are in accordance with the recommendations of the European Commission to evaluate whether external forces are the main drivers of the contents of codes of these countries. The main research question we ask is: Do the codes of these seven countries reflect the recommendations of COM-284? We take this document as our point of reference, since we argue that it is, at least potentially, a highly relevant external force in determining the contents of codes of European Union countries. If the codes of the seven Eastern European countries to a large extent reflect the recommendations of COM-284, we take this as evidence for the fact that the contents of the codes are mainly driven by external forces, or in other words, that domestic forces are less important in determining the contents of codes. If, however, codes only marginally reflect the recommendations of COM-284, we conclude that code contents are mainly driven by domestic forces. We investigate this issue in the light of the ongoing discussion with respect to the forces that may drive the establishment and contents of codes of good governance.

The remainder of the paper is organised as follows. Section 2 provides an overview of corporate governance codes in Eastern Europe and a discussion of the theory on code diffusion. Section 3 discusses the research design and the methodology used in this paper. Section 4 describes the main findings of the paper and section 5 concludes. 


\section{Corporate governance and codes: A review}

\subsection{Corporate governance and the rationale of codes}

Corporate governance is about how principal-agent problems within companies can be mitigated. These principal-agent problems may be seen in the narrow context of the shareholder-oriented view. According to this view, the main problem at stake is how investors (principals) can make sure managers (agents) are committed to behaviour that contributes to optimizing the returns on their investors' resources. As Shleifer and Vishny (1997) put it: "Corporate governance deals with the ways in which suppliers of finance to corporations assure themselves of getting a return on their investment." Alternatively, principal-agent problems can be discussed from the broader perspective of the stakeholder-oriented view. According to this view, agency problems occur between managers as agents on the one hand and investors, employees and other possible suppliers of resources to the firm on the other hand (Monks/Minow 1995). ${ }^{1}$ In the context of discussions of corporate governance codes, the shareholder view is most relevant, which is why we continue focusing on this perspective.

According to the shareholder view there are two main types of agency problems that may occur: between management and shareholders, and between controlling and minority shareholders (La Porta et al. 1999). Shareholders may mitigate agency problems by monitoring management and/or by punishing them (for example by demanding them to leave the company), once their behaviour does not lead to optimizing investment returns. Yet, monitoring and enforcement of contracts is costly. These costs may be especially high in emerging economies, where the institutional environments such as legal systems are less developed and where obtaining information about management and company performance is more difficult. This may then lead to free-rider behaviour of investors, leading to low effective monitoring and/or enforcement efforts, thereby increasing the agency problems.

One way to reduce agency problems and increase incentives for investors to monitor and enforce contracts is to create concentrated ownership. Concentrated shareholders may have stronger incentives to invest in monitoring and contract enforcement. La Porta et al. (1999) have actually shown that concentrated ownership is found in many countries around the world. Concentrated

1 Taking into account the interests of other stakeholders (i.e. not just investors) may also lead companies to change from narrowly defined profit maximizing objectives to objectives defined in terms of corporate social responsibility. In our analysis we refrain from discussing the specific type of company objectives that need to be optimized with the help of improved corporate governance practices. 
ownership, however, creates its own agency problems, i.e. that of the concentrated versus minority shareholders.

Another way of mitigating agency problems is establishing a set of rules, which describes how management of companies should behave in order to maximize the returns to investors. These rules may be either legally-binding or selfenforcing. In both cases, however, these results may help investors to mitigate agency problems and reduce agency costs of monitoring and enforcement of contracts. Such a set of rules is usually laid down in so-called corporate governance codes. These codes consist of recommendations relating to widely accepted best practices on the behaviour and structure of companies in their relations with shareholders. These practices refer to how companies should act so as to make corporate control by its owners more efficient and to increase corporate management efficiency. Best practices basically refer to issues such as shareholder protection, disclosure of information to shareholders, functioning and accountability of boards, remuneration of management and control systems.

\subsection{Corporate governance codes in Eastern Europe}

In Europe, the first code was established in 1992 with the issuing of the socalled Cadbury Report. This report was published after increased public concern about a series of unexpected failures of major British companies (Parkinson 1993). The Cadbury Report (1992) contained a code of best practices for listed companies. The widely accepted positive outcomes of the British code led to the adoption of similar codes of best practice in almost all other European countries, especially from 1998 onwards. By 2004, 22 European countries had established their own code, in some cases even more than one. In Eastern Europe, codes were establised since 2000 when Romania issued the first code. The Romanian initiative was followed by the establishment of codes in Czech Republic (2001), Poland, Russia, Slovak Republic, Russia (2002), Macedonia, Ukraine (2003), Lithuania, Slovenia, Hungary (2004), Latvia (2005) and Estonia (2006). Additionally, Czech Republic (in 2004), Poland (in 2002 and 2004) and Slovenia (in 2005) published revisions of the first version of their codes. The codes of these countries are non-legally binding, self-regulatory instruments, based on the "comply-or-explain" principle. This principle provides companies the freedom to deviate from best practices and recommendations included in the code, as long as they explain the reasons for doing so. However, the fact that in many cases such codes are adopted as listing requirements for associations and stock exchanges, gives them a rather formal (and in a sense a compulsory requirement) character (Dewing/Russell 2004). 


\subsection{The European Commission's communication on corporate governance (COM-284)}

In 2003, the European Commission released Communication 284 (COM-284) to the council and the European parliament, entitled "Modernising Company Law and Enhancing Corporate Governance in the European Union - A Plan to Move Forward". This communication contained an action plan with respect to improving corporate governance in Europe in a number of specific areas. ${ }^{2}$ Discussions about such an action plan were already taking place in the years before the European Commission published this document. In fact, COM-284 was the Commission's response to a report of the High Level Group of Company Law Experts, which was presented in 2002. The discussions within the European Commission were not taking place in isolation, but were building upon similar discussions taking place within other international organizations on this topic. This is also why the recommendations of COM-284 overlap with recommendations from an earlier report on codes published by the OECD (OECD 1999).

In the communication, the Commission acknowledges that standards in corporate governance are increasingly being set at an international level, with laws and regulations from many parts of the world (and especially from the United States with their Sarbanes-Oxley Act) outreaching to European companies and auditors, through their listings in foreign stock exchanges. According to the communication, new initiatives are needed at the level of the European Union in the field of corporate governance in light of the enlargement process of the Union, the ongoing integration of capital markets, the rapid development of new communication technologies and recent financial scandals such as Enron and WorldCom in the United States and Ahold and Parmalat in Europe. In this respect, the guidelines provided in the communication aim at harmonizing corporate governance practices within the European Union. The release of the communication on corporate governance may be seen as part of a larger plan to improve transparency of European corporations.

The communication addresses three basic fields in which a common approach should be adopted at the level of the European Union and in which adequate coordination of corporate governance codes should be ensured. These fields are: (1) enhancing corporate governance disclosure; (2) strengthening shareholder's rights; and (3) modernising the board of directors. With respect to each one of them, the communication addresses a set of priorities (or topics), which are listed below.

2 The communication does not have a legal status, but may be seen as a document providing guidance to governments regarding initiatives focusing on corporate governance adjustments. 


\section{Enhancing corporate government disclosure}

With respect to corporate governance disclosure, the Commission suggests that listed companies should be required to include a corporate governance statement in their annual report, covering the following priorities:

1. The operation of the shareholder meeting and its key powers;

2. The description of shareholder rights and how they can be exercised;

3. The composition and operation of the board and its committees;

4. The shareholders holding major holdings, and their voting and control rights as well as key agreements;

5. The other direct and indirect relationships between these major shareholders and the company;

6. Any material transactions with other related parties;

7. The existence and nature of a risk management system; and

8. A reference to a code on corporate governance, designated for use at national level, with which the company complies or in relation to which it explains deviations.

The Commission considers the adoption of such annual corporate governance statement as a short-term priority. In addition, two more issues are addressed regarding institutional investors:

1. To disclose their investment policy and their policy with respect to the exercise of voting rights in companies in which they invest; and

2. To disclose to their beneficial holders at their request how these rights have been used in a particular case.

\section{Strengthening shareholder rights}

In the field of shareholder rights, the Commission suggests that the following issues should be included in the codes:

1. Shareholders of listed companies should be provided with electronic facilities to access the relevant information in advance of General Meetings;

2. Shareholder democracy: The one share - one vote principle; and

3. Provisions for cross-border voting.

\section{Modernising the board of directors}

With respect to the board of governors, the Commission suggests that the Codes should include the following requirements: 
1. In areas where it is possible for conflicts of interest to rise (remuneration and supervision of the audit), decisions should be made by non-executive directors;

2. Disclosure of the remuneration policy;

3. Disclosure of details of remuneration of individual directors in the annual accounts;

4. Prior approval by the shareholder meeting of share and share option schemes in which directors participate;

5. Proper recognition in the annual accounts of the costs of such schemes for the company ; and

6. Collective responsibility of all board members.

\subsection{Domestic and external forces of codes: A theoretical discussion}

Aguilera and Cuervo-Cazzura (2004) provide a theory on the adoption of corporate governance codes of best practices by countries. They argue that code adoption may be based on both domestic and external forces. ${ }^{3}$ Domestic forces refer to demands for codes from investors who are confronted with the fact that their interests in the company are not taken care of in a correct way. These investors stress that their interests need to be protected better and codes may be a way to achieve this. Therefore, domestic forces stimulate the adoption of best practices by countries in order to improve the efficiency of the corporate governance system; codes are then introduced to close a perceived gap in the existing domestic corporate governance system.

External forces refer to pressures to create codes coming from increased globalization, opening up of financial markets and foreign institutional investors. If countries are increasingly opening up their economy to external influences and foreign capital, they will also be confronted with the fact that certain corporate governance practices are widely accepted elsewhere and they are expected to also implement such practices in order to be able to attract foreign capital (Aguilera/Cuervo-Cazurra 2004). We claim that the framework proposed to explain the adoption of a code also holds for its content, since it is this content that actually describes the nature of the best practices of corporate governance.

Using the above framework, the contents of codes in Eastern Europe may be explained by referring to both external and domestic forces. External forces influencing corporate governance in Europe are the globalisation and promulgation of international standards, the information technology and opening

3 Aguilera and Cuervo-Cazurra (2004) use a different terminology, referring to efficiency (domestic) and legitimacy (external). 
up of global financial markets that allows international investors to easily migrate their capital in quest of more favourable conditions, and the actions and communications of international institutions such as the OECD, the World Bank and the European Union institutions. These forces may lead to the harmonisation of corporate governance systems in Europe and stimulate convergence between the codes of different countries. In the framework of our paper, we focus on COM-284 as an important external force for convergence of code contents in Eastern Europe. As was mentioned, the contents of COM-284 to a large extent reflect earlier proposals made by, e.g. the OECD, as well as the best practices accepted by foreign investors.

However, next to external forces, domestic forces may influence the contents of corporate governance codes. Several studies have shown that corporate governance systems in Europe differ due to different institutional settings (Federowicz/Aguilera 2003). Differences in corporate governance systems may be reflected in different gaps in these systems among countries, leading to different contents of codes. In this case, codes tend to reflect the peculiarities of each country's distinct business environment, relating to differences in national regulatory environments, law systems, perceptions on the role of shareholders, agency relations and business cultures. According to Gregory and Simmelkjaer (2002) differences in corporate governance systems in the European Union result from differences in the relevant company laws, which at least until the early 1990s set almost exclusively the basic framework by which the companies were governed. Cuervo (2002) discusses several factors facilitating code divergence. In particular, he refers to local political interests, differences in the relevant legislation, differences in perceptions regarding the role that stakeholders should play in corporate governance, and differences between the countries' level of development.

In any case, if domestic forces are important in driving the contents of codes, we may expect to see a divergence, instead of convergence, of code contents between different Eastern European countries. In order to test whether external or domestic forces are important in explaining the contents of codes, we examine the extent to which the contents of the codes of the Eastern European countries that are (or are in the process of becoming) member of the European Union, are in concordance with COM-284. In other words, do the codes of these countries reflect the issues addressed by COM-284? We focus on this subset of Eastern European countries because this report may be especially relevant for them in shaping code contents. In the report it is acknowledged that corporate governance standards in Europe need to be improved in light of the enlargement process of the Union. Indirectly then, the report stresses the importance for Eastern European countries of accepting codes including widely accepted best practices as part of the process of their accession into the European Union. Some have claimed that the codes of these countries were to a large extent determined 
by demands resulting from the process of accession to the European Union (Berglöf/Pajuste 2005).

If the codes of these countries to a large extent reflect the recommendations of COM-284, we take this as evidence for the fact that the contents of the codes are mainly driven by external forces, or in other words, that domestic pressures are less important in determining the contents of codes. If, on the other hand, codes only marginally reflect the recommendations of COM-284, code contents are mainly driven by domestic forces.

\section{Research design}

This paper investigates corporate governance codes and their contents of seven Eastern European countries, i.e. Czech Republic, Hungary, Lithuania, Poland, Romania, Slovak Republic and Slovenia ${ }^{4}$. By mid 2005, these countries had established one or more codes. If a country has issued more than one code, which is the case for Czech Republic, Poland and Slovenia, we examine the code that is issued by the highest authority and use its most recent version. Table 1 provides information about the countries and codes used in the analysis.

Table 1. Corporate governance codes in Eastern Europe

\begin{tabular}{|l|c|c|c|}
\hline Country & EU Member & Number of codes & Year of issuing the code \\
\hline Czech Republic & Yes & 2 & 2001,2004 \\
\hline Hungary & Yes & 1 & 2004 \\
\hline Lithuania & Yes & 1 & 2004 \\
\hline Poland & Yes & 3 & $2002,2002,2004$ \\
\hline Romania & No & 1 & 2000 \\
\hline Slovak Rep. & Yes & 1 & 2002,2005 \\
\hline Slovenia & Yes & 2 & 2004,0 \\
\hline
\end{tabular}

Source: ECGI webpage (consulted June 2005): http://www.ecgi.org/codes/all_codes.php

When analyzing the the contents of the codes we focus on three main areas. These areas are enhancing corporate governance disclosure, strengthening shareholder's rights and modernising the board of directors, and reflect the areas prioritized in COM-284 as discussed in section 2. The analysis of the codes is based on a checklist of 18 questions, related to 18 of the 19 priorities mentioned in this section. ${ }^{5}$ In particular, the questions describe the contents of these

4 Estonia and Latvia are also European Union members and have recently established corporate governance codes. Yet, they are not included in the analysis, since at the time this research was carried out (June-September 2005) both countries did not yet have an official corporate governance code. Bulgaria, which is in the process of becoming a European Union member, does not yet have a code and is therefore also not included.

5 Our analysis does not take into account priority number 6 ("Material transactions with other related parties") since COM-284 provides no further information about who these related parties are considered to be. 
priorities in terms of best practices of corporate governance. With the check list we evaluate whether or not the priorities as mentioned in COM-284 can be found in a particular code.

All questions in the checklist can be answered with a simple YES or NO. If the answer to a particular question is YES this means the code contains a recommendation on a best practice as specified in the question. The nature of the question in all cases is that if the answer is YES, the recommendation in the code related to the question is assumed to (potentially) contribute to improving corporate governance practices. If the answer is $N O$ this means that a recommendation contributing to improving such practices is not present. Therefore, the higher the number of YES answers, the more a code contributes to improving corporate governance practices. Of course, whether a code really contributes to improving practices depends on the extent to which companies actually comply with the recommendations in the code and to what extent compliance leads to changes in corporate behaviour. We come back to this issue in the discussion and conclusion part of the paper (section 5). When presenting the results below we use " 1 " and " 0 "; " 1 " means a particular recommendation is incorporated in the code, a " 0 " means this is not the case.

\section{An analysis of the contents of Eastern European codes}

\subsection{Comparing code contents with COM-284}

Table 2 provides an overview of the comparison of the national codes of seven Eastern European countries with respect to recommendations included in COM284 to enhance corporate governance disclosure (topics 1-10, excluding topic 6).

The results in table 2 provide the following picture. First, the majority of the seven codes include recommendations on:

- Disclosure of the composition and operation of the board and its committees (topic 3: 5 out of 7);

- Disclosure of the existence and nature of the risk management system (topic 7: 6 out of 7); and

- A reference to a code on corporate governance, designated for use at national level, with which the company complies or in relation to which it explains deviations (topic 8: 6 out of 7).

Second, a minority of the codes include recommendations on the following topics:

- Disclosure of the shareholders holding major holdings, and their voting and control rights as well as key agreements (topic 4: 3 out of 7); 
- Disclosure of the other direct and indirect relationships between these major shareholders and the company (topic 5: 3 out of 7);

- Disclosure by institutional investors of their investment policy and their policy with respect to the exercise of voting rights in companies in which they invest (topic 9: 2 out of 7); and

- Disclosure by institutional investors of how they have used voting rights in particular cases, if their beneficial holders request this information (topic 10: 2 out of 7).

Table 2. Enhancing corporate governance disclosure

\begin{tabular}{|l|c|c|c|c|c|c|c|c|c|c|}
\hline & $(1)$ & $(2)$ & $(3)$ & $(4)$ & $(5)$ & $(7)$ & $(8)$ & $(9)$ & $(10)$ & $\begin{array}{c}\text { Total number of } \\
\text { recommendations }\end{array}$ \\
\hline $\begin{array}{l}\text { Czech } \\
\text { Republic }\end{array}$ & 1 & 1 & 1 & 1 & 1 & 1 & 1 & 1 & 1 & $\mathbf{9}$ \\
\hline Hungary & 0 & 0 & 1 & 0 & 0 & 1 & 1 & 0 & 0 & $\mathbf{3}$ \\
\hline Lithuania & 1 & 1 & 1 & 0 & 0 & 1 & 0 & 0 & 0 & $\mathbf{4}$ \\
\hline Poland & 1 & 1 & 0 & 0 & 0 & 0 & 1 & 0 & 0 & $\mathbf{3}$ \\
\hline Romania & 0 & 0 & 0 & 0 & 0 & 1 & 1 & 0 & 0 & $\mathbf{2}$ \\
\hline $\begin{array}{l}\text { Slovak } \\
\text { Rep. }\end{array}$ & 1 & 1 & 1 & 1 & 1 & 1 & 1 & 1 & 1 & $\mathbf{9}$ \\
\hline Slovenia & 0 & 0 & 1 & 1 & 1 & 1 & 1 & 0 & 0 & $\mathbf{5}$ \\
\hline $\begin{array}{l}\text { Total } \\
\text { number } \\
\text { of } \\
\text { countries }\end{array}$ & $\mathbf{4}$ & $\mathbf{4}$ & $\mathbf{5}$ & $\mathbf{3}$ & $\mathbf{3}$ & $\mathbf{6}$ & $\mathbf{6}$ & $\mathbf{2}$ & $\mathbf{2}$ & \\
\hline
\end{tabular}

Notes: The table provides an overview of the comparison of the national codes of 7 Eastern European countries with respect to recommendations to enhance corporate governance disclosure. For each country, the table shows whether recommendations regarding topics on enhancing corporate governance disclosure are found in its corporate governance code. A "1" means a particular recommendation is incorporated in the code, a " 0 " means this is not the case. The numbers 1-10 between brackets refer to the topics on which recommendations are formulated. These recommendations are:

1. Description of the operation of the shareholder meeting and its key powers;

2. Description of shareholder rights and how they can be exercised;Disclosure of the composition and operation of the board and its committees;

3. Disclosure of the shareholders holding major holdings, and their voting and control rights as well as key agreements;

4. Disclosure of the other direct and indirect relationships between these major shareholders and the company;

5. Disclosure of the existence and nature of a risk management system;

6. Reference to a code on corporate governance, designated for use at national level, with which the company complies or in relation to which it explains deviations.

7. Disclosure by institutional investors of their investment policy and their policy with respect to the exercise of voting rights in companies in which they invest; and

8. Disclosure by institutional investors of how they have used voting rights in particular cases, if their beneficial holders request this information.

Note that recommendation 6 ("Disclosure of material transactions with other related parties") is excluded from the analysis since COM-284 provides no further information about who these related parties are considered to be. 
What can we conclude from the results in table 2? Before discussing the results in some detail, we want to emphasize that it is difficult to draw firm conclusions with respect to the relative importance of the nine recommendations in enhancing disclosure. Thus, we do not intend to make statements about which of the results on individual recommendations is most important in order to improve corporate governance practices.

Taking this caveat into account, most country codes appear to express the importance of disclosing information on who is operating the company and specify the nature of their tasks and operations. Also, the codes generally agree with the best practice to demand companies to formally report on their corporate governance practices and the extent to which they conform to the best practices of the national code. It should be noted, however, that this last recommendation may be relatively loosely related to improving corporate governance. As discussed, all codes follow the comply-or-explain principle, giving companies a lot of degrees of freedom to diverge from generally accepted best practices and stick to governing their business "as usual". The results also indicate that the codes in Eastern Europe are reluctant demanding openness from shareholders in general and from institutional investors in particular, with respect to their holdings and policies as major owners of companies. This apparent deviation from the generally accepted best practices as proposed by the European Union may be a reflection of domestic forces, i.e. specific characteristics of corporate governance systems of these countries. In many Eastern European countries controlling shareholders and blockholdings are an important feature (Berglöf/Pajuste 2003; Postma/Hermes 2003). Companies with controlling shareholders generally have less incentive to disclose information (Berglöf/Pajuste 2005).

Table 3 provides the results of comparing the national codes with recommendations in COM-284 regarding strengthening shareholder's rights (topics 11-13). One recommendation (topic 11) deals with providing shareholders information based on which they can evaluate the company's performance and operations. As such, following this recommendation does not directly lead to strengthening shareholder's right, but it may support shareholders on deciding to exercise their rights in case these rights are explicitly available. The two other recommendations (and especially topic 12) are more directly linked to strengthening shareholder's rights.

The results in table 3 show that most country codes (except for the Romanian code) include a recommendation covering topic 11. The two other recommendations are found in only 2 of the seven country codes. So, in general terms the recommendations that would most directly strengthen shareholders' rights are to be found only in a minority of the codes. This appears to signal an obvious deviation from the generally accepted best practices on shareholder's rights as perceived by the European Commission in COM-284. This deviation 
may again reflect domestic forces, and again one possible explanation may be the existence of large controlling shareholders. Large controlling shareholders may have incentives to have weak minority shareholder's rights in order to maintain controlling power. Accepting this interpretation of the results, this would lead to the conclusion that the majority of the Eastern European corporate governance codes do not help solving the agency problem between controlling and minority shareholders.

Table 3. Protecting shareholders' rights:

\begin{tabular}{|l|l|l|l|l|}
\hline & $(11)$ & $(12)$ & $(13)$ & $\begin{array}{l}\text { Total number of } \\
\text { recommendations }\end{array}$ \\
\hline Czech Republic & 1 & 0 & 1 & $\mathbf{2}$ \\
\hline Hungary & 1 & 0 & 0 & $\mathbf{1}$ \\
\hline Lithuania & 1 & 1 & 0 & $\mathbf{2}$ \\
\hline Poland & 1 & 0 & 0 & $\mathbf{1}$ \\
\hline Romania & 0 & 0 & 0 & $\mathbf{0}$ \\
\hline Slovak Republic & 1 & 0 & 1 & $\mathbf{2}$ \\
\hline Slovenia & 1 & 1 & 0 & $\mathbf{2}$ \\
\hline $\begin{array}{l}\text { Total number of } \\
\text { countries }\end{array}$ & $\mathbf{6}$ & $\mathbf{2}$ & $\mathbf{2}$ & \\
\hline
\end{tabular}

Notes: The table provides the results of a comparison of codes with respect to recommendations regarding strengthening shareholder's rights (topics 11-13). For each country, the table shows whether recommendations regarding topics on enhancing corporate governance disclosure are found in its corporate governance code. The numbers 11-13 between brackets refer to the topics on which recommendations are formulated. These recommendations are:

- Shareholders of listed companies should be provided with electronic facilities to access the relevant information in advance of General Meetings;

- Shareholder democracy: the one share-one vote principle;

- Provisions for cross-border voting.

In table 4 we compare codes with the recommendations of COM-284 on modernizing the board of directors (topics 14-19). Four of the six recommendations deal with board remuneration (topics 15-18); one recommendation deals with board responsibilities (topic 19) and one considers conflicts of interests of board members (topic 16).

The results show that almost all country codes (except for Poland and Romania) include the recommendation related to conflicts of interests. Moreover, the majority of codes also cover the recommendation on board responsibilities (4 out of 7). With respect to board remuneration the results are mixed. On the one hand, all codes include the recommendation on the disclosure of the remuneration (i.e. fixed and variable components) of individual directors in the annual accounts (topic 16). On the other hand, however, none of the codes, except one, contain a recommendation regarding the recognition in the annual accounts of the costs for the company of share and share option schemes of directors (topic 18). For the other two recommendations on remuneration results are in between the two extreme cases described above. According to us, the 
results on remuneration suggest that codes include recommendations more easily when they are less demanding in terms of disclosing sensitive information. For example, disclosing the fixed and variable remuneration of individual directors as such is less sensitive than providing details about exactly how option and share schemes are constructed and how much they cost the company. This suggests that the codes leave some room for companies being opaque about their remuneration policies.

Table 4. Modernizing board of directors:

\begin{tabular}{|l|c|c|c|c|c|c|c|}
\hline & $(14)$ & $(15)$ & $(16)$ & $(17)$ & $(18)$ & $(19)$ & $\begin{array}{c}\text { Total number of } \\
\text { recommendations }\end{array}$ \\
\hline Czech Republic & 1 & 1 & 1 & 1 & 0 & 1 & $\mathbf{5}$ \\
\hline Hungary & 1 & 1 & 1 & 1 & 0 & 0 & $\mathbf{4}$ \\
\hline Lithuania & 1 & 0 & 1 & 1 & 0 & 1 & $\mathbf{4}$ \\
\hline Poland & 0 & 1 & 1 & 0 & 0 & 0 & $\mathbf{3}$ \\
\hline Romania & 0 & 0 & 1 & 0 & 0 & 0 & $\mathbf{1}$ \\
\hline Slovak Rep. & 1 & 0 & 1 & 1 & 0 & 1 & $\mathbf{4}$ \\
\hline Slovenia & 1 & 0 & 1 & 0 & 1 & 1 & $\mathbf{4}$ \\
\hline $\begin{array}{l}\text { Total number of } \\
\text { countries }\end{array}$ & $\mathbf{5}$ & $\mathbf{3}$ & $\mathbf{7}$ & $\mathbf{4}$ & $\mathbf{1}$ & $\mathbf{4}$ & \\
\hline
\end{tabular}

Notes: The table shows results of comparing codes regarding recommendations on modernizing the board of directors (topics 14-19). For each country, the table shows whether recommendations regarding topics on enhancing corporate governance disclosure are found in its corporate governance code. The numbers 14-19 between brackets refer to the topics on which recommendations are formulated. These recommendations are:

- In areas where it is possible for conflicts of interest to rise (remuneration and supervision of the audit), decisions should be made by non-executive directors;

- Disclosure of the remuneration policy;

- Disclosure of details of remuneration of individual directors in the annual accounts;

- Prior approval by the shareholder meeting of share and share option schemes in which directors participate;

- Proper recognition in the annual accounts of the costs of such schemes for the company; and

- Collective responsibility of all board members.

Summarizing the results in tables 2-4, we come to the following two conclusions. First, and most importantly, when looking at the results per country, we see that, whereas the Czech and Slovak Republic codes include a high number of all recommendations (16 respectively 15 of 18), the Romanian code includes only 3; Hungary and Poland have codes including somewhat less than half of the 18 recommendations (8 respectively 7); the Lithuanian and Slovenian codes include little more than half of all recommendations (10 respectively 11). These results, presented in table 5, show a remarkable dispersion with respect to the extent to which codes reflect the recommendations of COM-284. If we relate these results to our theoretical set-up, this seems to indicate that for the Czech and Slovak Republic codes are mainly driven by external forces. In contrast, for countries such as Poland, Hungary and especially 
Romania, code contents are mainly driven by domestic forces, since they only marginally reflect the recommendations of COM-284.

A second and related conclusion is that the Eastern European code contents differ quite substantially among themselves. For only 6 of the 18 recommendations discussed here, we find similar results for the seven countries, in the sense that these recommendations are or are not included in at least 6 country codes. In particular, only the Czech and Slovak Republic codes seem to be very similar, and the Hungarian code appears to be only weakly similar to the Polish and the Romanian code. These findings seem to be in contrast to what others have argued in the past, i.e. that codes appear to be rather similar (Gregory/Simmelkjaer 2002; Cromme 2005). This would again support the idea that, at least for some of the seven codes, domestic forces may be important drivers of code contents.

Table 5. Number of recommendations covered by Eastern European Codes:

\begin{tabular}{|l|c|}
\hline Country & Number of the 18 recommendations covered \\
\hline Czech Republic & 16 \\
\hline Hungary & 8 \\
\hline Lithuania & 10 \\
\hline Poland & 7 \\
\hline Romania & 3 \\
\hline Slovak Republic & 15 \\
\hline Slovenia & 11 \\
\hline
\end{tabular}

Source: Tables 2-4

\subsection{Code contents and country characteristics}

In the previous section we concluded that, at least for some of the Eastern European codes (and especially for Romania, Hungary and Poland) domestic forces may explain for the fact that the code contents differ from the recommendations of COM-284. Other codes, however, covered a majority or almost all of these recommendations, pointing out the importance of external forces in driving code contents. Can these different outcomes be understood by looking more closely at country-specific characteristics related to corporate governance?

In table 6 we provide data on a set of country-specific variables that describe, or are related to the corporate governance system. In particular, we have selected variables characterizing the progress made in terms of enterprise restructuring and large-scale privatization, extent of investor protection, existing anti-director rights, the aggregate quality of governance (i.e. at the national level), and stock market development. We use measures of the extent of enterprise restructuring and large-scale privatization, taking the average of these two measures (ERPR). These measures are included in the EBRD transition index dataset (EBRD 2005). They reflect the existence or absence of soft budget constraints, reforms 
to promote corporate governance and private ownership of former state-owned enterprises. To measure investor protection we use a variable that refers to stock market integrity (SMI), based on the work by Pistor (2000). This variable covers a range of characteristics of stock markets and their regulations related to investor protection, including conflict of interest rules, independence of shareholder registers, insider trading rules, mandatory disclosure threshold, state control of capital market supervision agency, and the independence of capital market supervision (Berglöf/Pajuste 2005). Our measure of anti-director rights $(A D R)$ is based on the index created by La Porta et al. (1997); we have used the data reported in Berglöf and Pajuste (2005) on this measure for the seven countries in our analysis. With respect to the aggregate quality of governance, we use the governance data set, constructed by the World Bank (Kaufmann et al. $2003)$. This data set contains information on regulatory quality $(R Q)$, rule of law $(R L)$ and control of corruption $(C C)$. Finally, in order to measure stock market development ( $S M D)$, we use the stock market capitalization, i.e. the total market value of listed shares at the stock exchange as a percentage of GDP. This measure is usually taken as an indicator of stock market development. The data for this measure come from a World Bank data set on financial markets (Beck et al. 2006). The data for enterprise restructuring and large-scale privatization, as well as the aggregate governance indicators are for the year 2002, for investor protection and anti-director rights, we have data for 1998, and for stock market development we use the average of stock market value to GDP ratio for 19952002. For all variables, higher values indicate better performance of the corporate governance system and related institutions.

Table 6 also presents the data on the number of the 18 recommendations of COM-284 that is included in the code of a country. These data are presented in the second column of the table. As discussed before, these data show the extent to which the content of a code reflects internationally accepted best-practices.

The results in table 6 do not provide a very clear pattern of relationships between the number of recommendations covered by a country code and the various corporate governance variables. Still, the figures do invite drawing two tentative conclusions on the relationship between the extent to which code contents reflect internationally accepted best-practices and corporate governance characteristics. First, lower values of enterprise restructuring and large-scale privatization are associated with a lower number of recommendations covered by a country code. This result may be expected: if companies are still confronted with soft budget constraints (weak financial discipline and lax credit policies), if the government has initiated few reforms to promote corporate governance and if there is low private ownership of former state-owned enterprises, then there is less pressure to establish internationally accepted best practices of corporate governance, such as the one recommended by the European Commission in their report. 
Table 6. Code contents and country characteristics

\begin{tabular}{|l|c|c|c|c|c|c|c|c|}
\hline & RECCOV & $\begin{array}{l}\text { ERPR } \\
(2002)\end{array}$ & $\begin{array}{l}\text { SMI } \\
(1998)\end{array}$ & $\begin{array}{l}\text { ADR } \\
(1998)\end{array}$ & $\begin{array}{l}\text { RQ } \\
(2002)\end{array}$ & $\begin{array}{l}\text { RL } \\
(2002)\end{array}$ & $\begin{array}{l}\text { CC } \\
(2002)\end{array}$ & $\begin{array}{l}\text { SMD } \\
(1995 \\
- \\
2002)\end{array}$ \\
\hline $\begin{array}{l}\text { Czech } \\
\text { Repub } \\
\text {-lic }\end{array}$ & 16 & 3.67 & 5 & 3 & 1.12 & 0.74 & 0.38 & 0.091 \\
\hline $\begin{array}{l}\text { Hunga } \\
\text { ry }\end{array}$ & 8 & 3.67 & 3 & 3 & 1.21 & 0.90 & 0.60 & 0.162 \\
\hline $\begin{array}{l}\text { Lithua } \\
\text { nia }\end{array}$ & 10 & 3.33 & 1 & 3.75 & 0.98 & 0.48 & 0.25 & 0.016 \\
\hline Poland & 7 & 3.33 & 4 & 3 & 0.67 & 0.65 & 0.39 & 0.049 \\
\hline $\begin{array}{l}\text { Roma- } \\
\text { nia }\end{array}$ & 3 & 2.67 & 1 & 3 & 0.04 & -0.12 & -0.34 & 0.007 \\
\hline $\begin{array}{l}\text { Slovak } \\
\text { Rep. }\end{array}$ & 15 & 3.67 & 2 & 2.5 & 0.76 & 0.40 & 0.28 & 0.068 \\
\hline $\begin{array}{l}\text { Slove- } \\
\text { nia }\end{array}$ & 11 & 3 & 3 & 2.5 & 0.84 & 1.09 & 0.89 & 0.029 \\
\hline
\end{tabular}

Notes: RECCOV is the number of recommendations covered by a country code; EPRP is the average value of two variables measuring the extent of enterprise restructuring and large-scale privatization (source: EBRD 2005); SMI is a measure of investor protection including conflict of interest rules, independence of shareholder registers, insider trading rules, mandatory disclosure threshold, state control of capital market supervision agency, and the independence of capital market supervision (source: Pistor 2000); $A D R$ is anti-director rights as measured by La Porta et al. (1997) (source: Berglöf/Pajuste 2005); $R Q$ is regulatory quality, $R L$ is rule of law and $C C$ is control of corruption (source: Kaufmann et al. 2003); SMD is stock market development, measured as the total value of listed shares trade at the stock exchange as a percentage of GDP (source: Beck et al. 2006).

A second tentative conclusion points out that very low levels of stock market development are associated with low numbers of recommendations covered by a country code. Again, Romania stands out in this respect; it has the least developed stock market combined with a very low number of recommendations covered by the code. Yet, this association also seems to hold for the other country codes, with the clear exception of Hungary. This relationship between code contents and stock market development may be explained by pointing out that demands for protecting shareholder interests will be stronger in countries with better developed stock markets. In these countries stock markets are an important part of the financial system and individuals have invested a relatively large part of their wealth in shares of companies. Therefore, more developed stock markets are associated with a higher demand for codes covering 
recommendations related to information disclosure on corporate governance, strengthening shareholders' rights and modernizing board of directors. ${ }^{6}$

The above discussion indicates that domestic forces may at least to some extent help shaping the contents of corporate governance codes. Note, however, that our discussion is based on only seven country codes, which does not allow exploring this issue with the help of formal empirical tests.

\section{Conclusions and discussion}

This paper has compared the contents of corporate governance codes of seven Eastern European countries with respect to best practice recommendations of the European Commission in its COM-284 report on disclosure rules, strengthening shareholder rights and modernising boards. In particular, we have asked ourselves the question to what extent the codes of seven Eastern European countries reflect the priorities set by the Commission. If the national codes to a large extent reflect the recommendations put down in COM-284, we take this as evidence for the fact that the contents of the codes are mainly driven by external forces, or in other words, that domestic pressures are less important in determining the contents of codes. If, however, codes only marginally reflect the recommendations of COM-284, we conclude that code contents are mainly driven by domestic forces.

We show that the codes of the Eastern European countries on average cover only around 50 per cent of the recommendations of the European Commission. Moreover, the results are rather different between countries: whereas the Czech and Slovak Republic both have established that are quite close to the Commission's recommendations, Romania and to a lesser extent also Hungary and Poland have codes that considerably deviate from these recommendations. Our findings do not support the claims of those who point out that the codes appear to be rather similar (Gregory/Simmelkjaer 2002; Cromme 2005).

According to our analytical framework the results suggest that the contents of codes of countries to a greater or lesser extent are shaped by domestic forces related to country-specific characteristics of corporate governance systems. We found some support for the fact that factors such as the extent of enterprise

6 We also observe that in the case of Romania very low values of the aggregate quality of governance (RQ, RL and CC) are associated with a very low number of recommendations covered by the Romania corporate governance code. The contents of the Romanian code may therefore reflect the extremely low quality of governance: weak rules of law, low regulatory quality and low control of corruption do not provide a supportive environment to establish a code that conforms to generally accepted best practices of corporate governance. However, the association between the quality of governance and code contents does not seem to exist for the other countries in our sample, which prohibits us from making any generalizations about the existence of a relationship between the two. 
restructuring, large-scale privatization, stock market development, and lesser also the quality of governance at the national level, may help shape code contents.

We acknowledge our approach has a number of limitations. First, we only focused on seven country codes of European Union members, which does not allow for using formal empirical tests to explore the relationship between code contents and country-specific characteristics of the corporate governance system. Broadening the scope of our research by taking into account codes of non-European Union member countries does not help solving this problem, since, as was mentioned in section 2.2 , by early 2006 only twelve Eastern European countries had established a code. Therefore, future research might evaluate code contents of all countries (currently there are 49 country codes; Heugens/Otten 2005) to evaluate the relationships between code contents and characteristics of corporate governance systems.

Second, we have used the recommendations of the European Commission as a proxy for internationally accepted best practices of corporate governance, putting external pressure on the introduction and the contents of codes in Eastern European countries. Our research method is an indirect way of analysing the extent to which external forces shape codes. Our research could be extended by looking more carefully at processes describing how governments have been supported by international organizations such as the European Union and OECD in setting up their national codes.

\section{References}

Aguilera, R./Cuervo-Cazzura, A. (2004): Codes of Corporate Governance Worldwide: What is the Trigger?, in: Organization Studies, 25, 3, 415-443.

Akkermans, D/Ees, H./Hermes, N./Hooghiemstra, R./Laan, G./Postma, T./Witteloostuijn, A. (2006): Corporate Governance in the Netherlands: An Analysis of Compliance with the Tabaksblat Code in 2004, Unpublished Paper, University of Groningen, the Netherlands.

Beck, T./Demirguc-Kunt, A./Levine, R. (2006): A New Database on Financial Development and Structure 1960-2004, Washington DC: World Bank. Available at:

Berglöf, E./Pajuste, A. (2003): Emerging Owners, Eclipsing Markets? Corporate Governance in Central and Eastern Europe, in: Cornelius, P.K./Kogut, B.(eds.): Corporate Governance and Capital Flows in a Global Economy, Oxford: Oxford University Press.

Berglöf, E./Pajuste, A. (2005): What Do Firms Disclose and Why; Enforcing Corporate Governance and Transparency in Central and Eastern Europe, in: Oxford Review of Economic Policy, 21, 2, 178-197.

Cromme, G. (2005): Corporate Governance in Germany and the German Corporate Governance Code, in: Corporate Governance: An International Review, 13, 3, 362367. 
Cuervo, A. (2002): Corporate Governance Mechanisms: A Plea for Less Code of Good Governance and More Market Control, in: Corporate Governance: An International Review, 10, 2, 84-93.

Dayha, J./McConnell, J.J./Travlos, N.G. (2002): The Cadbury Committee, Corporate Performance, and Top Management Turnover, in: Journal of Finance, 57, 1, 461-483.

Dedman, E. (2000): An Investigation into the Determinants of UK Board Structure Before and After Cadbury, in: Corporate Governance: An International Review, 8, 2, 133153.

Dedman, E. (2002): The Cadbury Committee Recommendations on Corporate Governance: A Review of Compliance and Performance Impacts, in: International Journal of Management Reviews, 4, 4, 335-352.

Dewing, I./Russell, P. (2004): Regulation of UK Corporate Governance, Oxford: Blackwell Publishing.

European Bank for Reconstruction and Development (EBRD) (2005): Transition Report 2005, London: EBRD.

European Commission (2003): Modernising Company Law and Enhancing Corporate Governance in the European Union - A Plan to Move Forward, Brussels, 21.5.2003, COM-284 final.

Federowicz, M./Aguilera, R. (eds.) (2003): Corporate Governance in a Changing Economic and Political Environment, Basingstoke: Palgrave Macmillan.

Gregory, H./Simmelkjaer, R.T. (2002): Comparative Study Of Corporate Governance Codes Relevant to the European Union And Its Member States, Weil: Gotshall \& Manges LLP.

Heugens, P./Otten, J. (2005): Corporate Governance Reforms Around the World, Discussion Paper Series No. 05-08, Tjalling C. Koopmans Research Institute, University of Utrecht, The Netherlands.

Kaufmann, D./Kraay, A./Mastruzzi, M. (2003): Governance Matters III: Governance Indicators for 1996-2002, World Bank Policy Research Working Paper No. 3106, Washington DC: World Bank.

La Porta, R./Lopez-de-Silanes, F./Shleifer, A./Vishny, R. (1997): Legal Determinants of External Finance, in: Journal of Finance, 52, 1131-1155.

La Porta, R./Lopez-de-Silanes, F./Shleifer, A. (1999): Corporate Ownership Around the World, in: Journal of Finance, 54, 2, 471-517.

Monks, R.A.G./Minow, N. (1995): Corporate Governance, London: Blackwell Publishers.

OECD (1999): OECD Principles of Corporate Governance, Paris: OECD.

Parkinson, J. (1993): Corporate Power and Responsibility: Issues in the Theory of Company Law, Oxford: Oxford University Press.

Pistor, K. (2000): Patterns of Legal Change: Shareholder and Creditor Rights in Transition Economies, in: European Business Organization Law Review, 1, 59-110.

Postma, T./Hermes, N. (2003): Institutions, Corporate Governance, and Corporate Governance Institutions: The Case of Estonia, in: Journal for East European Management Studies, 8, 3, 263-292. 
Shleifer, A./Vishny, R. W. (1997): A Survey of Corporate Governance, in: Journal of Finance, 52, 737-783.

All seven Eastern European codes are available through the ECGI page (June 2005): http://www.ecgi.org/codes/all_codes.php 